\title{
Building New Selves: Identity, "Passing," and Intertextuality in Zoë Wicomb's Playing in the Light
}

\section{David Hoegberg}

Department of English, Indiana University Purdue University-Indianapolis (IUPUI), Indianapolis, IN, USA

501H Cavanaugh Hall, 425 University Blvd, Indianapolis, IN 46202

Email: icic100@iupui.edu or dhoegberg@aol.com

Cell phone: $317-435-2935$

David Hoegberg teaches postcolonial and British literature at Indiana University Purdue UniversityIndianapolis (IUPUI). He has published articles on Aphra Behn, Derek Walcott, J. M. Coetzee, Athol Fugard, Chinua Achebe, and Zoë Wicomb in numerous peer-reviewed journals. He is currently at work on a monograph on Wicomb and intertextuality.

This is the author's manuscript of the article published in final edited form as:

Hoegberg, D. (2018). Building new selves: identity, "Passing," and intertextuality in Zoë Wicomb's Playing in the Light. 


\section{Building New Selves: Identity, "Passing," and Intertextuality in Zoë Wicomb's Playing in the Light}

This article examines Zoë Wicomb's wide-ranging use of intertextuality in the novel Playing in the Light to explore the links between identity construction and postcolonial authorship. Focusing on the characters as intertextual agents, I argue that the three coloured women on whom the novel focuses - Helen, Marion, and Brenda—use texts in distinctive ways that illuminate their struggles to position themselves in South Africa's complex and changing racial landscape. Racial "passing" is one form of a larger pattern in the novel of the use of citation and imitation to achieve specific ends. By embedding the citations of Helen and Marion within the citation-rich narrative of Brenda, Wicomb lays bare the mechanisms of identity construction within a work that stages and highlights its own intertextual practices.

Keywords: Zoë Wicomb; Playing in the Light; intertextuality; race; passing; origins; coloured; identity; bricolage; South Africa

Zoë Wicomb's 2006 novel Playing in the Light focuses on the stories of three women, each with a different relationship to the social constructions of "coloured" identity in South Africa. The earliest parts of the novel's chronologically disjointed narrative tell of Helen Campbell and her husband John, who move from the countryside to Cape Town at about the time apartheid's racial laws were taking effect in the late 1940s. As light-skinned coloureds, they are able to "pass" for white, though at the cost of severing most of their ties to their coloured families. The main impetus for their transition comes from Helen, whose intense ambition for a "respectable whiteness" associated with the English white identity is rooted in her idea of colouredness as a shameful condition. ${ }^{1}$ Helen's daughter Marion grew up during the apartheid years believing that she was white and, in the novel's "present" time frame, is

\footnotetext{
${ }^{1}$ Wicomb, Playing in the Light, 131.
} 
the owner of a successful travel agency in post-apartheid South Africa. Marion discovers in the course of the novel that her parents were "play whites" who had engaged in a careful and sustained imposture. Her encounter with colouredness thus comes in adulthood and is complicated by the prejudices against coloureds she has internalized from her white upbringing. The third important woman in the novel is Brenda Mackay, a young employee in Marion's office, whom Marion befriends as she embarks on the journey of discovery that leads to the exposure of her parents' passing. Brenda lives in Bonteheuwel, a mostly coloured working-class township, has a university education, and wants to be a writer. For Brenda, colouredness is neither a shame to be escaped nor a mystery to be solved but simply one aspect of a multi-faceted South African identity she is in process of constructing for herself.

It is tempting to read these three women as representatives of different stages in an inevitable historical trajectory from coloured shame in the apartheid years to coloured pride in the early years of the "Rainbow Nation." Uplifting as such a narrative of progress might be, however, it would ignore the question of these characters' own agency in the construction of specific coloured identities. Zmitri Erasmus, in a much-quoted essay, argues that coloured identities are distinguished "by cultural borrowing and creation under very specific conditions of creolization."2 This creolization, or bricolage, as Erasmus also calls it, "involves the construction of an identity out of elements of ruling as well as subaltern cultures." ${ }^{3}$ Erasmus insists that such borrowing does not "invalidate" the subjectivities so created. "Coloured identities are not simply Apartheid labels imposed by whites. They are made and re-made by coloured people themselves in their attempts to give meaning to their everyday lives."4 Similarly, in her 1998 essay "Shame and identity: the case of the coloured

\footnotetext{
${ }^{2}$ Erasmus, Coloured by History, 16.

${ }^{3}$ Ibid., 6 .

${ }^{4}$ Ibid., 16.
} 
in South Africa," Wicomb refers to "the fictional nature of identity construction" and to the role of cultural borrowing in this fictional process. ${ }^{5}$ In place of a biological model of coloured identity based on the mixing of two supposedly pure races, both Erasmus and Wicomb suggest a textual model in which individual agency or self-fashioning interacts with the given materials of culture. Where Erasmus emphasizes the positive aspects of coloured borrowing, however, Wicomb sees a range of outcomes, not all of them positive. The popular 1980s musical District Six, for example, attempted to forge a supposedly "pure” coloured identity by imitating "North American cultural conventions and musical forms," yet the "contradiction" between the message of purity and the borrowed artistic form was lost on coloured audiences hungry for a narrative of authenticity they could set alongside those of blacks and Afrikaners. ${ }^{6}$

The problem with such narratives, Wicomb argues, is not the borrowing itself but the deliberate or unwitting concealment of the bricolage involved in identity construction, which creates an illusion of authenticity that remains dependent on the "epistemological structures of apartheid." ${ }^{\prime 7}$ In an earlier essay, Wicomb criticizes the display during ANC rallies in the 1990s of a traditional African courtship dance as an "official" example of national culture, with no acknowledgment that the placing of this dance in a new context transforms its meaning significantly. "Since the dance is itself a reworking of tradition that seeks to conceal that transformation, coming clean or coming to terms with such transformations seems essential." ${ }^{8}$ Such "coming clean" would involve analyzing the concealed re-workings that lie behind representations such as the musical or the dance to expose the elements out of which

\footnotetext{
${ }^{5}$ Wicomb, "Shame and Identity," 95.

${ }^{6}$ Ibid.

${ }^{7}$ Ibid., 94.

${ }^{8}$ Wicomb, "Tracing the Path," 250.
} 
they have been constructed and the interests driving their creation and reception. Analysis such as this can take place in critical works but also in fiction, as Wicomb argues in her 2005 essay on intertextuality. The postcolonial writer who deliberately borrows from the culture and literature of the imperial center has an opportunity to expose the perceived purity and authenticity of that culture as an illusion that occludes its multiple borrowings. "For the postcolonial writer it is the transformative effect of intertextuality that is of significance. Frequently our settings in disjunction with citations from colonial texts produce postcolonial irony, and if we are doomed to echolalia, it is also the case that repetition re-presents, reverses or revises, or simply asks the reader to reflect on indeterminate meanings produced by citations, meanings that destabilise received views." ${ }^{9}$ Notice here that for Wicomb "echolalia" - a compulsive and involuntary tendency to echo others' work — may be an inescapable feature of the postcolonial condition. What she calls "postcolonial irony" does not replace echolalia but coexists with it on a spectrum of modes of postcolonial intertextuality ranging from simple imitation to creative and ironic adaptation. ${ }^{10}$ In a situation of inescapable borrowing, the question for the writer becomes how to take charge of the intertextual processes most productively to move toward "a symbiotic rather than a hierarchical relationship" with one's culture and history, including literary history. ${ }^{11}$ To turn

\footnotetext{
${ }^{9}$ Wicomb, "Setting and Intertextuality," 146.

${ }^{10}$ The distinction between passive and active forms of imitation runs throughout Wicomb's critical writing. In "Shame and Identity" Wicomb cites with approval Frederic Jameson's distinction between pastiche and parody as different modes of repetition or re-use. In "Culture Beyond Color?" she calls for a "radical pedagogy" that will help to create "an interracial culture of readers and writers who are not passive consumers of culture, but rather who interrogate received views" (32).

${ }^{11}$ Ibid., 150.
} 
"genealogical filiation" into literary "fraternity," Wicomb argues, the writer must find ways to assert her own agency in relation to her predecessors while at the same time allowing for a shared agency in relation to her readers. ${ }^{12}$ Exposure of others' concealed borrowings must be made in a work that does not attempt to conceal its own.

The emphasis in Wicomb's critical work on the parallel challenges of coloured identity and postcolonial authorship helps to explain why she makes all of her coloured characters in Playing in the Light inveterate users of texts, both oral and written. Helen, John, Marion, and Brenda quote, parody, mock, remember, and recycle a dizzying variety of texts throughout the novel, from popular songs, nursery rhymes, travel brochures, and fashion magazines to Sophocles, Shakespeare, T. S. Eliot, and the Bible. These references make the novel a particularly dense example of postcolonial intertextuality, a fact that has often been noted in the critical discussion. Dorothy Driver, M. J. Daymond, J. U. Jacobs, Stephane Robolin, Meg Samuelson, Fiona McCann, and Andrew van der Vlies have all acknowledged what McCann calls the "rich intertextual quality of this novel" and have glossed particular allusions insightfully. ${ }^{13}$ Almost invariably, however, these critics refer only to Wicomb, or more vaguely to the novel itself, as the agent of its intertextual references. While Wicomb is, of course, the ultimate source of the novel's references, viewing her as the only source closes off discussion of the decisions Wicomb herself has made to portray her characters as intertextual agents. One notable exception to this critical tendency is van der Vlies's argument, toward the end of his 2010 essay, that Brenda should be viewed as the narrating consciousness, if not the actual author, of the entire novel. Reading the narrative as the product of one of the fictional characters in it, says van der Vlies, lends "delightful irony" to

\footnotetext{
${ }^{12}$ Ibid., 147, 150.

${ }^{13}$ McCann, "Revisiting the Past," 70.
} 
certain moments in the text and "new resonances" to its allusions to canonical literature. ${ }^{14}$ Van der Vlies correctly perceives that the portrayal of Brenda as the potential author produces a "staging of artifice" that "consciously undermines the effect - and affect - of realism," 15 but he does not extend this principle to the other characters in the novel, who are also makers of allusions, nor does he perform the systematic rereading of the novel's allusions his insight seems to demand.

As users of texts, all three of the coloured women in Playing in the Light share in the predicament of the postcolonial author and display a range of intertextual modes and motives. By placing much of the novel's intertextual activity within the fictional frame, in the minds and actions of these characters, Wicomb embeds their acts of citation in specific social contexts. Full interpretation of the allusions, then, requires us to take citation, agent, and context into account. While the citations lay bare the mechanisms of identity construction and their basis in language and textuality, however, biological approaches to racial identity still carry persuasive power in the world of these characters. Thus, the task of "building new selves," as Helen puts it, must always compete with existing selves that have been socially constructed in racial terms. ${ }^{16}$ In this context, the question "Who can describe his generation?" posed in a biblical citation associated with Helen, takes on a wider significance for the novel as a whole. If racial identities come with ready-made definitions of one's "generation" or origins, building a new self requires changing or re-defining the terms in which one's given identity has been described. ${ }^{17}$

\footnotetext{
${ }^{14}$ van der Vlies, “The Archive," 595.

${ }^{15}$ Ibid., 596-7.

${ }^{16}$ Wicomb, Playing in the Light, 128.

${ }^{17}$ In the passage from Acts 8:33 quoted in the novel (page 118), the word "generation" translates the Greek term, genean, which derives from genea, meaning race, family, generation, or kind.
} 


\section{Helen}

The Campbells' project of playing white begins with an intertextual interpretation of John's spoken discourse by the superintendent of the Cape Town Traffic Department. When John applies for a job, unaware that "the job of traffic cop was reserved for whites," the superintendent "heard with nostalgia the sunburnt young man's rough, rolling r's as the language of a white farmer." 18 Interpreting John's speech through the lens of his "nostalgia," the superintendent hears it as a reference to the language of his own rural childhood. John quickly realizes that he is being taken for white but decides to test this hypothesis. "Ja-nee Oubaas, he said to the kindly superintendent - although the Campbells would never, not in a million years, have called a white man baas - we can't have any messing about with the heartbeat of the city." ${ }^{19}$ When John sees that "the boss did not flinch at the Oubaas, read it as an affectionate mark of respect rather than a sign of racial deference," the test is complete and John is, in the context of the Traffic Department at least, effectively white. ${ }^{20}$ This scene highlights the dual agency of author and reader in Wicomb's model of intertextuality. The superintendent's decisive "reading" of John's discourse is partly a function of his own memories and assumptions, factors that lie outside of John's control, and partly a function of John's deliberate citation of a distasteful discourse to achieve a specific purpose. John's whiteness, then, is neither wholly the superintendent's gift nor John's achievement but emerges as an effect of this intertextual relationship.

John's acceptance as a white strikes Helen as an almost miraculous revelation of the possibilities for individual agency in the process of identity construction. "It was a gift, a sign

\footnotetext{
${ }^{18}$ Wicomb, Playing in the Light, 127.

${ }^{19}$ Ibid.

${ }^{20}$ Ibid.
} 
from above that they should set about the task of building new selves." ${ }^{21}$ Realizing that she is not stuck with the coloured identity imposed on her by apartheid, however, Helen is also unwilling to settle for the white Afrikaner identity John has attained. She aspires instead to a higher form of whiteness and sets about with religious fervor to build a white English identity by means of deliberate citations according to the example John has provided. Having already anglicized her maiden name from Karelse to Charles, Helen now insists that they marry and move from their coloured neighborhood to "a decent white area" and then to a house in Observatory. ${ }^{22}$ She models her English pronunciation on that of SABC radio announcers and her bodily posture on "the instructions of her well-thumbed etiquette book." ${ }^{23}$ After her application for a job as white saleslady is successful, Helen and John are both employed as whites and seemingly on a path of upward mobility. Helen's mother, whose skin is too dark to pass for white, conspires in this signifying by playing "a walk-on role as servant" in their household in order to "provide a history of an old family retainer," taking the nickname "Tokkie" after Marion is born. ${ }^{24}$ Even their flower garden is a meaningful text: the cuttings brought by Tokkie from her employer's larger, English-style garden in the upscale suburb of Constantia function as quotations linking the Campbells to a visual tradition of English prosperity. $^{25}$

Although Helen embraces the creative possibilities provided by a textual model of identity construction, her self-concept remains tied to biological concepts of race and racemixture. Feeling trapped by a biological "destiny determined by the vagaries of their distant

\footnotetext{
${ }^{21}$ Ibid., 128.

${ }^{22}$ Ibid., 128, 130, 131.

${ }^{23}$ Ibid., 125, 139.

${ }^{24}$ Ibid., 132, 134.

${ }^{25}$ Ibid., 133.
} 
European ancestors," she imagines her project as a "crusade" to "redeem" her forebears from the sin of having sex with "hotnos and slaves." 26 This attachment to the shame-inducing terminology of miscegenation keeps her bound within the epistemological structures of apartheid even as she plots her escape from one of its racial categories. ${ }^{27}$ Because she thinks of her own "generation" as lying in sin, she turns increasingly to biblical texts and teachings, with their offers of redemption, to construct an identity that is both Christian and white. Her belief in her own inherited sinfulness also motivates her obsessive concern for order and fear of discovery. Helen sees racial passing not as a clever game of posturing but as a difficult calling that demands a life of discipline, vigilance, and self-denial.

The most important element in Helen's pursuit of a new identity is the legal affidavit signed by Councillor Carter. As with John's experience at the Traffic Department, however, Helen's agency in producing this document is limited by the agency of others. At her first appointment with him, Carter notices signs of her colouredness despite her efforts to speak and to look white. Carter's eyes “drilled instead through the buttoned shirt and found ... blushing brown nipples set in dark aureoles." ${ }^{28}$ Making full use of his power as a reader of Helen and as an author of the affidavit, Carter demands that Helen meet him after hours three more times, extorting sexual favors from her in exchange for his official signature.

These two official encounters through which whiteness is conferred on the Campbells_-John's in the Traffic office and Helen's in Carter's office—unfold as intertextual exchanges, as scenes of speaking, reading, and writing. ${ }^{29}$ Given the racially and sexually degrading nature of Helen's experience, we can understand why she resents how

\footnotetext{
${ }^{26}$ Ibid.

${ }^{27}$ Ibid., 131.

${ }^{28}$ Ibid., 139.

${ }^{29}$ Compare Robinson, "It takes one," 716, on passing as an encounter between two ways of reading.
} 
easy it was for John to become white. Whereas John had "watched whiteness fall fabulously, like an expensive woman, into his lap," Helen must endure a man pawing his way into her bodice. ${ }^{30}$ The sexual image in John's case is merely a simile, but Helen's greater ambition prompts her to commit adultery. To manage the guilt she feels, Helen turns to the Bible, and especially to the New Testament book of Acts. From Father Gilbert's preaching at St. Luke's, she latches onto "his idea of opportunity as a window,"31 a reference to the converted Saul's escape from persecution through a window in Acts 9:25. When she obtains the affidavit from Carter, Helen explicitly connects "Act No. 30" of the South African parliament (i.e. the Population Registration Act of 1950) to the Acts of the Apostles:

Like the signs and wonders of the Acts of the Apostles, the miracles where men and women rose and made their beds and started their lives anew speaking in fresh tongues, so Helen was remade. The Sunday-school texts of her girlhood, learnt by heart and seldom understood, grew clear with the music of meaning, of revelation. ${ }^{32}$

If Act No. 30 was an attempt to confine people like the Campbells within the restrictive racial category of "coloured," the affidavit, obtained at great cost, is her window of escape into the world of white privilege, a new written "Act" that revises how Act No. 30 applies to Helen and John in particular. The reference to speaking in "fresh tongues" connects Helen's experience to John's in the Traffic Department and to Acts chapter 2, in which the apostles preach to a multilingual crowd and "every man heard them in his own language." 33

\footnotetext{
${ }^{30}$ Wicomb, Playing in the Light, 127, 144.

${ }^{31}$ Ibid., 141.

${ }^{32}$ Ibid., 144.

${ }^{33}$ Acts 2:6; King James Version.
} 
Helen's feeling of having been "remade" is also presented as a rereading of the "Sunday-school texts" of her youth. These might have included Mark 10:29-30, in which rewards of "an hundredfold" are promised to those who turn away from their former lives for Jesus' sake, and John 8:11, in which Jesus forgives an adulterous woman. And they would certainly have included the one Sunday-school card from her collection that Helen saved, which quotes a passage in Acts in which an Ethiopian eunuch reads a passage from Isaiah and is accepted as a Christian convert. Placed in the context of her encounter with apartheid, such texts now seem to Helen to portray a god who not only forgives but demands the radical social remaking she has attempted. "She may have been defiled, but she'd also been obliterated, and believing in the miracle of rebirth, her own thoughts had remained pure. Not once did Helen doubt her actions." 34 Maintaining a steadfast faith that "necessity . . . could not be offensive to a God who exalted the poor," she finds in the Bible implicit justification for racial passing as a form of conversion and of escape from oppression. ${ }^{35}$

Having obtained legal certification of her whiteness from Councillor Carter, Helen revels in a newfound social acceptance represented by the foot-washing ceremony presided over by Father Gilbert. Gilbert's ministry is set in explicit comparison to that of Trevor Huddleston, "the young firebrand priest of the north" 36 who, in his 1956 memoir Naught For Your Comfort, describes the Maundy Thursday ceremony in which he "washed the feet of African students, stooping to kiss them," as the chief liturgical example of Christian identification with others, and thus, in the context of apartheid South Africa, an act of protest. ${ }^{37}$ Father Gilbert's decision to make "his mark" at St. Luke's by instituting the

\footnotetext{
${ }^{34}$ Wicomb, Playing in the Light, 144.

${ }^{35}$ Ibid., 145.

${ }^{36}$ Ibid., 159.

${ }^{37}$ Huddleston, Naught for Your Comfort, 75.
} 
Maundy Thursday ceremony is a clear reference to Huddleston's example, but in an all-white parish its meaning is entirely different. ${ }^{38}$ Gilbert challenges tradition by including a woman among the "chosen twelve" and picks Helen for her apparent "modesty and dependability," thus substituting a mild statement about gender equity for Huddleston's resounding protest against apartheid. ${ }^{39}$ The great irony, however, is that Gilbert has included a non-white in his ritual without knowing it. For Helen, Gilbert's selection of her is "nothing short of a triumph" because he has chosen her with no thought of her race, only her gender. ${ }^{40}$ In passing this very public test of her new identity, she believes, "the last trace of her sins would be washed away, and she would finally be white as the driven snow." ${ }^{11}$ Since Helen's feet, like her "blackberry nipples," are tell-tale markers of her colouredness, she has John intensify his regular shaving and grooming of them, so that she emerges from the church service "cleansed and bathed in holiness, her very feet tamed and certificated by God." 42 Rather than a demonstration of the Anglican Church's racial inclusiveness, the ceremony becomes Helen's triumphant emergence into full white acceptance.

Despite Helen's success in using creative reading and citation strategies to forge her new identity, her emphasis on the bodily aspects of this ritual shows her continuing reliance on a biological concept of race. To her, the ceremony is a way for her to "finally be white." To achieve this finality, she attempts to erase all evidence of her past self, deliberately concealing the textual basis of her transformation. She wants no description of her "generation"- - of the process by which she became white - to be possible. One piece of

\footnotetext{
${ }^{38}$ Wicomb, Playing in the Light, 160.

${ }^{39}$ Ibid.

${ }^{40}$ Ibid.

${ }^{41}$ Ibid.

${ }^{42}$ Ibid., 147, 161.
} 
evidence that survives, however - the Sunday school card that (ironically) Marion thinks “leads nowhere” in her search for clues to Helen's inner life—perfectly symbolizes Helen's transformation. ${ }^{43}$ The sign of the card's origin in the Moravian Mission Church has, like Helen's own Moravian Mission background, been reduced to a "barely perceptible smudge." 44 The quoted text from Isaiah, "As a sheep led to his slaughter or a lamb before his shearer is dumb, so he opens not his mouth," expresses Helen's sense of racial transformation (the "shearing" of her outer layer) as a form of death, and its apparently rhetorical question, "Who can describe his generation?", seems to justify her silence about her coloured origins. ${ }^{45}$ Furthermore, the illustration that accompanies the text depicts (according to Marion) two bearded white men "poring over a book." 46 These men can only be the Ethiopian eunuch and Philip the Apostle, who are discussing the passage from Isaiah, but the illustrator has silently turned the Ethiopian man white. In this picture, then, as in Helen's experience, the Ethiopian is not accepted into the church as a black, but rather is miraculously turned white in the process of being turned Christian, as if his textual encounter has transformed both his spirit and his body. ${ }^{47}$ Helen's attachment to this card, with its deliberate whitewashing of the scene of reading, illustrates how deeply she remains embedded in the racial structures of apartheid.

\footnotetext{
${ }^{43}$ Ibid., 119.

${ }^{44}$ Ibid., $118,140$.

${ }^{45}$ Ibid.

${ }^{46}$ Ibid., 117.

${ }^{47}$ Compare Wicomb's "Five Afrikaner Texts," in which she discusses a reverse version of such a mismatch between image and text. See also her essay "To Hear the Variety of Discourses": "contradictory relations between image and text demand that the image be re-read, and reassessment of the visual information involves a change in the underlying presuppositions" (43-44).
} See Daymond, "Shadow Stories," for an alternate reading of this card and its relation to Helen. 
She uses her intertextual agency not to challenge the government's system of racial classification or to convey to others the textually constructed nature of racial identities, but only to move from a lower to a higher category within the system.

\section{Marion}

Given her parents' story of passing via citation, it should be no surprise that Marion is in a sense defined by textuality from the beginning. In their effort to give Marion "the ease of whiteness," Helen and John tell her nothing of their coloured families or pasts. ${ }^{48}$ Instead, they "learned to use the vocabulary of the master race" both in public and in private, ${ }^{49}$ and this vocabulary — in effect a second language to her parents_-becomes Marion's first language, the linguistic air she breathes. Helen sees Marion as a chance to "see her project [of becoming English-white] completed in the child," ${ }^{50}$ while John associates her with the liminal figure of the mermaid, using this literary citation to express his greater ambivalence toward their new identities. As an adult, Marion retains her connection to the stories and imagery of mermaids without being fully aware of their implications. ${ }^{51}$

After attending an Afrikaans primary school and obtaining a university degree at Stellenbosch University, a stronghold of Afrikaner culture, Marion reaches adulthood as, for all she knows, a full member of the "master race." 52 Predictably, then, many of the textual reference points she uses to construct her identity are consumer magazines and travel

\footnotetext{
${ }^{48}$ Wicomb, Playing in the Light, 152.

${ }^{49}$ Ibid., 124.

${ }^{50}$ Ibid., 125.

${ }^{51}$ See Samuelson, “Oceanic Histories," 552-556, for a detailed reading of the mermaid figure in relation to Marion.

${ }^{52}$ Wicomb, Playing in the Light, 131-32, 68, 124.
} 
brochures, texts with a strong visual component that are focused on enjoyment of the life of privilege she has inherited. In her apartment, "her interiors seem to spring from the glossy pages" of Home and Garden magazine. ${ }^{53}$ In decorating her office kitchen, "she followed a recent style feature in Cosmopolitan to the letter." ${ }^{54}$ In these examples, Marion's emphasis on the visual is coupled with rote imitation of textual models; like her mother, she displays her prosperity by citation.

Interestingly, Marion's careful attention to surface appearances seems to be the catalyst that leads her toward deeper discoveries of her family's history. She is drawn to the Cape Times article on Patricia Williams not by the news story, but by the photograph. In her initial study of the newspaper in her office, she sees "something arresting about the face." 55 Later, in her apartment, although she still avoids reading the article, "the eyes of the stranger hold hers accusingly." ${ }^{56}$ Prompted by this accusing look, Marion skims the first paragraph of the report and learns of Patricia Williams's torture while in detention in the 1980s. Only then does Marion notice that "the face retains the memory of these acts. There is a hint of asymmetry, of distortion, as if the marks of a fist lie as a trace just below the healed features. ${ }^{" 57}$ Here, as the photograph prompts Marion to read and the reading leads her toward a closer observation of the photograph, image and text work together to prompt Marion's further investigations.

The photograph's command to "remember" applies first of all to the history of antiapartheid struggle and police brutality, a history Marion has hitherto chosen to ignore. When

\footnotetext{
${ }^{53}$ Ibid., 2.

${ }^{54}$ Ibid., 35 .

${ }^{55}$ Ibid., 49.

${ }^{56}$ Ibid., 54.

${ }^{57}$ Ibid., 54-55.
} 
Marion, a moment later, sees the ghostly face floating on the water, another remembrance begins to take shape. "Recognition beats like a wave against the picture window: Tokkie, it is Tokkie's face on the water. Not the smiling, doting woman . . . but rather the stern face that the little girl . . glances up at." ${ }^{58}$ Now it is her personal history Marion remembers, Tokkie's face captured at a moment when the mask of cheerful family retainer (or doting grandmother) has slipped and a stern, brooding woman, "lost in reverie," becomes visible. ${ }^{59}$ This association of Patricia Williams with Tokkie is the moment that sends Marion on her journey of self-discovery. Although she will not learn until later that she has detected in Williams' face not only a history of violence but a family connection to herself, reinterpreting this childhood memory in the context of what she reads and sees in the newspaper leads her to a puzzle that begs to be solved. Marion immediately applies this new lesson in reading to John's spoken discourse as she questions him over the phone about Tokkie and becomes convinced that there is "something secret, something ugly, monstrous, at the heart of their paltry little family." ${ }^{60}$ A chain of readings has taken her from the newspaper article to the trace of former injury in Williams' face to the trace of Tokkie in the same face to the trace of a "monstrous" family secret beneath the surface of John's spoken words.

Although Marion's sense of identity is shaken by these discoveries, her sense that identity is biologically determined is not. "She knows that the mystery is about her own birth," but if her parents have kept a troubling truth from her, it can only be that "she is an adopted child." 61 If the dark-skinned Tokkie is somehow involved in the mystery, Marion

\footnotetext{
${ }^{58}$ Ibid., 55.

${ }^{59}$ Ibid.

${ }^{60}$ Ibid., 58.

${ }^{61}$ Ibid., 62.
} 
"knows" that "she cannot be biologically connected to Tokkie." ${ }^{62}$ Believing in her “inalienable right ... to know her origins," Marion embarks on a quest to describe her generation that takes her to Wuppertal with Brenda, fully convinced that she is looking for her "real" white parents. As if to prepare Marion for her unexpected discovery, however, they encounter on the way the unusual Outa Blinkoog, an itinerant folk artist who makes shiny and playful objects out of "found things that others throw away." 63 Although he would not appear in any tourist guide book, he seems to the women "a brightly coloured creature from mythology, a messenger from the gods" and a "man out of a storybook." ${ }^{64}$ Seemingly sprung from a text, Blinkoog is also a maker of texts, not only the visual art works he carries on his cart but also "his prize possession, an unbleached linen cloth covered in roughly written text and embroidered line drawings" that apparently contains his ongoing life story. ${ }^{65}$ This text, in both its content and its physical form (the embroidery is done by Blinkoog's women friends), presents to Marion an alternate concept of identity, not as something fixed at birth but as continually in process of being made and re-made, shaped by the agency of the self but also by others. As a maker of "Beautiful Things" from "scraps and broken bits," and as himself "a bundle of bric-a-brac" with one green eye and one black one, ${ }^{66}$ Blinkoog is an emblem of the creative bricolage of coloured culture and identity described by Zmitri Erasmus.

The interview with Mrs. Murray that follows highlights another aspect of coloured culture: its political conservatism. Pressed by Brenda's questioning, Mrs. Murray admits that

\footnotetext{
${ }^{62}$ Ibid.

${ }^{63}$ Ibid., 89.

${ }^{64}$ Ibid., 87, 90.

${ }^{65}$ Ibid., 88-89.

${ }^{66}$ Ibid., 88, 89, 86-87.
} 
"the decent coloured people of Wuppertal voted for the Nationalists" in the 1994 election. ${ }^{67}$ This tendency to look toward white leadership must be counted as one of the cultural elements that shaped Marion's grandmother and her mother. The pro-Nationalist vote, in fact, is the last topic of conversation we hear about before Mrs. Murry exclaims, while tending to Marion's swollen foot, "Oh gits, ... you look the spitting image of Mrs Karelse my dear!"68 It is significant that Marion is recognized as belonging to the Karelse family in this setting and at this point in the novel's narration. In an important sense, Marion's whiteness originated here, in a community of conservative coloureds, with the grandmother Mrs. Murray describes as "respectable" and "decent," and the mother who pursued "decency" at all costs. ${ }^{69}$ Marion is the logical outcome of Helen's romance with whiteness, the completion of her project. But Marion's rediscovered colouredness also begins here. When Mrs. Murray wipes Marion's feet with a towel, we become aware that this scene re-enacts the Maundy Thursday ritual that marked Helen's triumphant emergence into whiteness, but now it is Marion's whiteness that is seemingly washed away as she emerges into colouredness. Only it is not quite so simple. The intense pain in her foot that prompted Mrs. Murray's ministrations in the first place signals the onset of a new understanding for Marion of her life as a mermaid, the pain of a displacement that cannot be undone.

As John's and Helen's new racial identities began with being read by another, so does Marion's begin with Mrs. Murray's reading of her as the "spitting image" of her coloured grandmother. Marion's first reaction to this revelation is an odd feeling that her head is not her own, as if someone else's face has been recognized as coloured while some essential core of her selfhood remains white. The next morning, her resistance to the new information takes

\footnotetext{
${ }^{67}$ Ibid., 96.

${ }^{68}$ Ibid., 97.

${ }^{69}$ Ibid., 95, 167.
} 
the form of a feeling that she is "without a skin" and then becomes a "terrible emptiness" within her that stimulates both a search for answers and a desire for further travel. ${ }^{70}$ Having begun her journey to Wuppertal as a quest for an alternate set of parents, Marion must now try to understand how and why her parents' whiteness - and her own — was textually constructed. Thus, upon her return she becomes a dogged investigator of the texts relating to her parents' past as she attempts to piece together their story. We see her studying her mother's belongings, researching in the library, and interrogating John repeatedly.

Marion's trip to Europe is an extension of this research. Marked at its beginning by the floating image of a mermaid and her baby, this journey becomes for Marion a further exploration of her family origins, but most especially a search for her absent mother. ${ }^{71}$ While she is in London, "the sensation of a hole, a curious, negative definition of the familiar emptiness, develops in her chest," causing "tears [to] flow afresh in self-pity, pity for the grown woman who wants a mother." 72 Her maternal longing leads directly to her decision to begin reading the South African novels recommended to her by a woman at Clarke's Bookshop in Cape Town. The novels offer a continuation of Marion's education, a supplement to the newspapers, libraries, and personal interviews she has consulted so far. ${ }^{73}$ As Marion reads Nadine Gordimer's 1974 novel The Conservationist, however, she finds that the novel genre provides a different kind of experience. "It doesn't stop the tears-for the man who doesn't know what's up, for the boy who can't speak to his father, for the absence

\footnotetext{
${ }^{70}$ Ibid., 101, 102.

${ }^{71}$ Ibid., 186.

${ }^{72}$ Ibid., 189.

${ }^{73}$ Robolin ("Properties of Whiteness," 364-68) offers a detailed analysis of the Gordimer and Coetzee novels Marion reads as examples of the anti-pastoral tradition in South African literature.
} 
of a mother, for her own ludicrous identification of the black farmhand with her father." 74 Marion weeps in turn for the novel's main character, Mehring (a wealthy white businessman who, like her, drives a Mercedes), for his son Terry (who, like her, longs for his mother), for his reliable farmhand Jacobus, and especially for an unnamed play-white coloured girl Mehring encounters in the novel's penultimate scene. "Is the girl," she thinks, "not, at some level, a version of herself? Of her mother?"75 The novel does not stop Marion's tears but transforms them from tears of self-pity to tears of sympathy for others in whom she can recognize aspects of her own experience. As Marion reads, she finds that "the hole in her chest seems to fill up with words." ${ }^{76}$ Her novel-reading experience has begun to give Marion inklings of the textual nature of identity, but it should not be understood as providing her with a new or ready-made identity to replace the white identity she is in process of surrendering. Rather, it sparks a process that generates multiple options. This process is intertextuality itself. Marion wonders: "Is this what reading is, or should be: absorbing words that take root, that mate with your own thoughts and multiply?"77 This question captures the combination of similarity and difference Marion has noticed between herself and the novel's characters, while Marion's metaphor of mating captures the dual agency of author and reader in Wicomb's model of intertextuality. The written words do not replace her own thoughts but mate with them and produce new thoughts that will have characteristics of both parents, a family resemblance that stems in part, but only in part, from the text she was reading.

Significantly, Marion's reproductive metaphor portrays in positive terms the very thing that so outrages Gordimer's Mehring about the play-white girl. In a striking passage,

\footnotetext{
${ }^{74}$ Wicomb, Playing in the Light, 190.

${ }^{75}$ Ibid.

${ }^{76}$ Ibid.

${ }^{77}$ Ibid.
} 
Mehring describes the girl as "a double fake." "78 Having noticed the straightened hair and heavy makeup that signal an attempt at racial passing, he derides her as "a dolled-up supermarket caricature of the tanned, long-waisted lucky ones who, aping pigment, provide in turn a model for one like this, who has it, to follow."79 The girl is a "double fake" because, in her attempt to look white, she models herself on magazine photos of white women who themselves are fakes for "aping pigment" in their pursuit of the suntan that serves as a marker of white beauty and status. This description of the intertextuality of passing does more than simply assert that passing is a matter of citing known white sources and models; it also calls into question the authenticity of the white sources themselves. Mehring's outrage fits his conservative white character, whereas Marion's tearful but willing acceptance that she and Helen are both "versions" of this girl shows an emerging distance from her white upbringing. Marion's ability to recognize herself in fictional characters is an extension of the vague and shadowy recognition of Patricia Williams that began her journey. It is fitting, then, that shortly after reading Gordimer's novel, Marion is able to resurrect a deeply repressed memory. "The thought comes boldly, with the old-fashioned sound of a typewriter, a headline being printed, letter by clacking letter: The Betrayal of Annie Boshoff." ${ }^{80}$ Marion's memory is framed as an act of self-conscious narration that revolves around two texts: a newspaper story, in which Annie's father declares himself to be a play-white and in love with his coloured mistress, and the "joint scrapbook with their favourite pictures of ballet dancers and film stars and things," which Marion and Annie had made and owned together. ${ }^{81}$ The scrapbook represents the shared process of bricolage by which the eight-year-old girls have

\footnotetext{
${ }^{78}$ Gordimer, The Conservationist, 262.

${ }^{79}$ Ibid., 261-2.

${ }^{80}$ Wicomb, Playing in the Light, 193.

${ }^{81}$ Ibid., 194.
} 
been constructing their early identities. The news story, which re-defines Annie as legally coloured and thus, in Helen's eyes, unfit to be Marion's friend, marks a loss of innocence, when socially defined racial categories begin to impinge on and co-opt this process. The moment of Marion's betrayal is when she "dropped the scrapbook into the dustbin in the backyard," ${ }^{82}$ choosing complicity with her mother's racial values over loyalty to her friend. Marion's ability to resurrect this memory and to see it as a "betrayal" is an important step in her growing self-awareness. If the loss of Annie's friendship was imposed on her by an apartheid system created by others, the disposal of their scrapbook, which could have been secretly saved and cherished, marks a moment in which Marion played an active role in the construction of her own whiteness, signing on, in effect, to Helen's “project." Just as important, however, is the narrative form in which Marion owns up to this responsibility, for this story she is now able to tell herself functions not only as a personal confession but also as an intertextual dialogue with the Gordimer novel she has just finished reading. The newspaper scandal that Mehring fears but avoids in Gordimer's penultimate scene becomes an actual scandal involving Mr. Boshoff in Marion's story. ${ }^{83}$ The scrapbook in Marion's story, like the supermarket magazines in Mehring's theory of passing, shows the process by which girls of any race construct identities out of pre-existing models, but what for Mehring was mere "faking" becomes in Marion's story a shared process that had formed the basis of a deep friendship. These transformations of elements from Gordimer's novel neatly demonstrate the intertextual process Marion had recently articulated, the mating of her thoughts with those of another to produce a narrative that is both a confession and a citation.

\footnotetext{
${ }^{82}$ Ibid., 195.

${ }^{83}$ See Gordimer, The Conservationist, 264.
} 
This inextricable combination of the deeply personal and the fictional, of what is owned and what is borrowed, suggests that Marion is coming to understand the textual basis of identities.

\section{Brenda}

Brenda is not only the youngest of the three women on whom Wicomb focuses but also the most grounded in her coloured identity in the "new" South Africa; she is neither attempting to escape it, like Helen, nor attempting to discover it, like Marion. She is, instead, attempting to discover what it means to be a coloured writer in a world that expects straightforward autobiography, and little else, from "someone like her." As she says to Marion at the end of the novel, "Writing my own story, I know, is what someone like me is supposed to do, what we all do, they say, whether we know it or not." ${ }^{84}$ Brenda's ambition to resist this imposed writerly identity of simplicity and directness helps to explain both the range and the strategic complexity of her uses of texts.

One of the novel's first portrayals of Brenda, focalized through Marion, gives an early indication of her skill in the ironic use of citations. After Boetie, Marion's conservative Afrikaner employee, introduces himself to Brenda using the formal title "Mr van Graan," Marion notices that Brenda "never misses an opportunity to use the Mister" in her conversations with him. ${ }^{85}$ This repeated citation of his own self-reference seems at first to grant him an almost apartheid-era deference, but Marion notes that Brenda also uses the pose of respect to "dump on him [tasks] that she clearly finds tiresome" while Boetie remains

\footnotetext{
${ }^{84}$ Wicomb, Playing in the Light, 217. In a 1990 interview, Wicomb had complained that "black women are supposed to write autobiography - whether they write in the third person or not, they're always received as if it's autobiographical, almost as if we're incapable of artifice, incapable of fictionalizing. That irritates me intensely" ("Wicomb," 93).

${ }^{85}$ Wicomb, Playing in the Light, 19, 20.
} 
unaware that he is being manipulated. ${ }^{86}$ Thus Marion wonders: "How does the girl manage to tread so delicate a boundary between respect and mockery?" ${ }^{87}$ Later, Marion becomes the unwitting butt of a similar mockery; as Marion and Brenda plan their trip to Wuppertal, Brenda quotes William Hazlitt's 1822 essay “On Going a Journey” without giving the source: "The soul of a journey is liberty, perfect liberty: to think, feel, do just as one pleases - to leave ourselves behind, she intones with fashionable irony." 88 Marion snorts in contempt, missing the double irony that Brenda has quoted an essay that enumerates the pleasures of travelling without companions, and that Hazlitt's essay is itself filled with quotations from earlier texts. Another example of Brenda's use of texts comes as she is enjoying the privacy of her newly-purchased single bed in her mother's cramped house in Bonteheuwel. She remembers a poem she had read in a Contemporary South African Literature course that "flew over her head" at the time, "but now the image returns" with new relevance. ${ }^{89}$ Such examples show that Brenda not only has access to a wide range of sources but also has the ability to reassess their meanings and their relevance to herself and her social situations.

Brenda's explanation of the practice of geleentheid, in which a lone traveler acquires a companion, works another variation on Hazlitt's essay in praise of solitary journeys. In one of her earliest reported conversations with Marion, Brenda explains the "complex business" whereby a passenger may join a trip that has already been planned. ${ }^{90}$ The driver "let[s] it be known that he has a spare seat," usually by means of a "rumour whose source cannot be

\footnotetext{
${ }^{86}$ Ibid., 20.

${ }^{87}$ Ibid.

${ }^{88}$ Ibid., 81.

${ }^{89}$ Ibid., 65.

${ }^{90}$ Ibid., 19.
} 
pinned down." 91 The rider then sends word back that she wants to go along and the two agree on a "financial contribution" and other details. ${ }^{92}$ Two features stand out in this otherwise rather ordinary description of how one catches a ride with the friend of a friend. First, the etiquette of geleentheid, says Brenda, demands a certain respect from the rider towards the driver; direct communication between them is discouraged and may be met with denial or hesitation, so the negotiation "works best with an intermediary." 93 Such deference helps to ensure that the driver remains "in the driver's seat," both literally and metaphorically, once the trip begins. Second, despite this deference, the journey is experienced by the rider as if it were her own choice, her desire. "It's like Fate. Suddenly you realize that that's exactly where you ought to go, where you'd like to go." ${ }^{94}$ As Brenda describes it, the rider adopts or internalizes the journey and its destination, thus becoming more than a merely passive passenger.

Brenda's journey to Wuppertal with Marion fits the pattern of a geleentheid except that the two negotiate the terms of their trip directly rather than through an intermediary. Although Marion's search for Tokkie is the impetus for the trip and she is the driver, Brenda's initial hesitation quickly turns to enthusiasm, and she has a noticeable influence on the trip's agenda. ${ }^{95}$ It is her search for origins, too, and she makes sure that they see the San rock paintings and the grave of Afrikaans poet C. Louis Leipoldt, two touchstones of

\footnotetext{
${ }^{91}$ Ibid.

${ }^{92}$ Ibid.

${ }^{93}$ Ibid.

${ }^{94}$ Ibid.

${ }^{95}$ Ibid., 73, 81.
} 
coloured culture in the Western Cape. ${ }^{96}$ Brenda's intertextual habits are on full display on this journey. Her desire to be a writer as well as a reader inspires a certain amount of respect for Leipoldt, but a respect mingled with irreverence: "Leipoldt was a fine poet; he also inherited his grandpa's love of coloured people, especially little boys. She giggles. At school we called him the moffie poet." ${ }^{97}$ Brenda then quotes ten lines of the poem "Krulkopklonkie" in Afrikaans, gives a mocking analysis of its meter, and exclaims, "what on earth is this wicked stuff doing in the Afrikaans canon?"98 Alongside the traditional reading of Leipoldt's poetry, which sees him as a canonical author and a pillar of Afrikaner nationalism, Brenda places another that turns him into a homosexual "passing" as heterosexual and turns the literary canon, like the "white" neighborhoods of apartheid, into a space that is vulnerable to infiltration.

After Marion's revelatory meeting with Mrs. Murray, Brenda further defines her identity as a budding writer through a multi-layered reading of T. S. Eliot. Significantly, Brenda takes over as driver for the journey home due to Marion's swollen foot. As Marion's unexpected news makes her feel that she "has no control" over her head and movements, Brenda takes control of their geleentheid, and they "drive in miasmal silence to Cape

${ }^{96}$ Brenda's literary itinerary on this journey follows a plan T. S. Eliot had laid out in "Tradition and the Individual Talent" and adapts it to the South African context. Eliot writes that "the mind of Europe ... is a mind which changes" and "this change is a development which abandons nothing en route, which does not superannuate Shakespeare, or Homer, or the rock drawing of the Magdalenian draughtsmen." Eliot, "Tradition," 51.

${ }^{97}$ Wicomb, Playing in the Light, 85.

${ }^{98}$ Ibid., 86. 
Town." 99 Brenda's paraphrase the next morning of T. S. Eliot's "Love Song of J. Alfred Prufrock," "Dare I eat a peach?", is inspired not only by the bowl of peaches in Marion's kitchen but also by the questions about Marion's identity that have been raised in the previous scene. ${ }^{100}$ Eliot's poem begins with an epigraph from Dante's Inferno in which Guido da Montefeltro responds to the question "who are you?"101 In the poem's main body, Prufrock answers that he is, in effect, two people. While in the presence of others, he remains carefully controlled, measuring out his life "with coffee spoons" (line 51), but in the privacy of his "love song" he confesses to inner longings for "strength" (line 80), intelligence, and romance, which he links, significantly, to the unattainable mermaids of the poem's concluding lines (124-131). ${ }^{102}$ Daring to eat a peach, like frolicking with mermaids, becomes for Prufrock one of several emblems for exposing his inner self to public view. Brenda has clearly diagnosed Marion as a similarly divided person whose hidden coloured identity has just been publicly exposed, so Eliot's poem provides an apt lens through which to view her.

Peaches are merely a prelude, though, to the main question in Brenda's mind of whether Marion knew all along of her coloured family and was caught out by Mrs. Murray. Brenda complains, "I feel a right fool. If you couldn't tell me the truth, you shouldn't have involved me at all." ${ }^{103}$ Marion replies, "So you think I'm a play-white; that I'm a fraud, that I lied to you - to the world?" "What else could I possibly think?" says Brenda. ${ }^{104}$ Eliot's poem, along with its epigraph, still operates as intertext here, for "fraud" is precisely the sin for

\footnotetext{
${ }^{99}$ Ibid., 97, 99.

${ }^{100}$ Ibid., 100.

${ }^{101}$ Dante, Inferno, 317.

${ }^{102}$ Eliot, "The Love Song of J. Alfred Prufrock," 130-135.

${ }^{103}$ Wicomb, Playing in the Light, 102.

${ }^{104}$ Ibid.
} 
which Guido da Montefeltro is punished in Dante's Inferno; Eliot's epigraph thus frames Prufrock's monologue as a statement of false humility and angst designed to win sympathy from unsuspecting readers. Appropriately, then, when Marion goes on to tell of her "dry, white childhood" and her current "terrible emptiness," Brenda is not impressed: "So it turns out you're coloured, from a play-white family, Brenda says. So what? . . . It's not such a tragedy being black, you know.... you need no longer speak in hushed tones - you're free to be noisy, free to eat a peach, a juicy ripe one, and free of the burdens of nation and tradition." ${ }^{105}$ Brenda's answer to Marion also outlines a more detailed answer to Prufrock, beginning with the analogy between class status in the Boston society of Eliot's Harvard years and racial status in South Africa. ${ }^{106}$ As Prufrock's anxiety over the peach masks a deeper fear of being exposed as lower class, so Marion's anxiety over her peach masks her fear of being exposed as coloured. In each case, Brenda implies, what frees you to eat a peach is undoing the link between status and essence. ${ }^{107}$

Brenda's use of Eliot's poem sheds light on the tensions between the two women at this crucial point in the development of their friendship. It also serves as a demonstration of intertextuality's endless fertility. By citing a work whose meanings crucially depend on the

${ }^{105}$ Ibid., 102. Brenda here rejects the notion of a separate "coloured nationhood" that Wicomb herself had critiqued in her essay "Shame and Identity." "Shame," 105.

${ }^{106}$ Stanley Sultan ("Tradition and the Individual Talent in 'Prufrock,"” 78) dates the composition of the poem to 1911, three years before Eliot's move to England and four years before the poem's first publication in Poetry magazine.

${ }^{107}$ Notice in this regard that poor table manners had been Helen's alibi for one of her most paininflicting actions: the exclusion of John's sister Elsie from her home on grounds of race. As John later explains the exclusion to Elsie, "It was something to do, he mumbled, with tea and cake and spitting on the Irish-linen cloth" (Wicomb, Playing in the Light, 168). 
relationship between work and intertext (and whose own sources-Dante, Shakespeare, Marvell, and others - are themselves relentlessly intertextual), Brenda links her experience to a branching web of books but also asserts her agency by reorienting Eliot's materials to a different place (South Africa) and a different topic (race).

Brenda's stint as temporary manager of the travel agency while Marion is in Europe can be read as an extension of the "geleentheid" metaphor in which Brenda takes over as "driver" of the business, seizing the opportunity to gain valuable work experience. Brenda also takes another important “opportunity” in Marion's absence, however, and this becomes the subject of the novel's final scenes in Marion's apartment and car. At first, Marion thinks Brenda has begun dating Geoff in her absence. Brenda assures her that she has not and offers a different explanation of her behavior: "They say it's history, centuries of history that comes between people, but I don't buy that. I can't be your friend because I'm too dependent on you. Right now I'd like to leave, but see how I can't flounce out, holding aloft keys slipped through my index finger like a movie star. I have to ask you to take me home." ${ }^{108}$ Brenda is troubled not so much by their different racial upbringings as by the class difference that exists between them in the present, the difference that makes one a driver and the other a rider. Both are well-educated women, and Brenda has shown her ability by taking over Marion's job, but the fact that Marion started in life with the economic advantages of whiteness creates a gulf between them.

The gulf deepens when Marion drives Brenda home after work the next day. In the car Brenda reveals that she has begun writing a work of fiction based on the stories of John's life she collected while Marion was away. "I found that your father's was the story that I

${ }^{108}$ Ibid. 
wanted to write, the story that should be written." ${ }^{109}$ This revelation is what prompts critic Andrew van der Vlies, as mentioned above, to argue that Brenda should be seen as "chief focaliser, if not author," of the narrative we have been reading. ${ }^{110}$ Wicomb's point in doing this, van der Vlies suggests, is not to equate Brenda with herself but to make Brenda the "agent" of an "ethics of authorial responsibility" that foregrounds the context-bound nature of any narrative representation. ${ }^{111}$ Brenda is shown in the process of "finding her own voice" as a writer and becoming "subject, rather than object of another's discourse." 112 Such an approach to Brenda also suggests a reading of her concept of geleentheid as a metaphor not only for power dynamics but also for writing as an inherently intertextual endeavor. ${ }^{113}$ When Brenda confesses her interest in John as a subject for fiction, "Marion swerves, pulls off the road," interrupting their drive in mid-journey. Marion is "cold with rage" at what she perceives as Brenda's imposture: "So in the guise of a do-gooder, you went back to prise more out of a lonely, senile old man." 114 When Brenda tries to explain the dramatic appeal of John's own racial impostures, Marion orders her out of the car. "Get out. I know my father's fucking story. Actually, Brenda says, I suspect you don't." "115 In this last exchange between the two women, Brenda reveals that the career she has sought to advance in Marion's absence is that of novelist, not travel agent. Her claim to have a deeper understanding of John's story

${ }^{109}$ Ibid., 217.

${ }^{110}$ van der Vlies, “The Archive," 595.

${ }^{111}$ Ibid., 597.

${ }^{112}$ Ibid., 597-8.

${ }^{113}$ In this light, it is significant that the root verb of "geleentheid," the Afrikaans word "leen," means both "to borrow" and "to lend."

${ }^{114}$ Wicomb, Playing in the Light, 217.

${ }^{115}$ Ibid., 218. 
than Marion has marks a transition for Brenda from being a reader and listener of others' stories (being "too dependent") to being a writer of her own version of those stories. It also marks, quite literally, the moment when she stops being a rider in Marion's car and strikes out on her own journey, turning from rider to writer.

The placing of this scene at the end of the novel, van der Vlies points out, invites attentive readers to perform a re-reading of many details that are, "in retrospect, open to being read as having been constructed by Brenda." 116 This would include certain allusions in the novel that can only come from a narrating consciousness, since they are not introduced by the characters, either in social discourse or in narrated private thoughts, but take place at the level of plot or structure. One such example occurs during the Wuppertal episode. As others have noted, the moment in which Mrs. Murray recognizes Marion as the "spitting image" of Helen's mother (i.e. Tokkie/Mrs. Karelse) is a reworking of the moment in Homer's Odyssey when the disguised Odysseus, having returned from the Trojan war to find his home beset by disrespectful suitors, is recognized by Eurycleia, a trusted family slave. ${ }^{117}$ Mrs. Murray looks up at Marion's face from below as she bathes Marion's swollen foot and sees the family connection. What has not been noted, however, is that this moment is also an allusion to Sophocles's tragedy Oedipus the King. Oedipus's name in Greek means "swollen foot” and refers obliquely to the wounds inflicted when his ankles were pinned together to ensure his demise. Thus, although Oedipus has been deceived by his adoptive parents about his origin, his name carries a trace of his true identity. ${ }^{118}$ Reading Marion's story in relation to Oedipus's throughout the novel makes sense for a number of reasons, but if Brenda is the

\footnotetext{
${ }^{116}$ van der Vlies, “The Archive," 594.

${ }^{117}$ Critics who mention this connection include Olaussen and Herrero.

${ }^{118}$ See Catenaccio, "Oedipus Tyrannus: The Riddle of the Feet," for a recent discussion of this wellknown theme in Sophocles's play.
} 
agent of this double allusion to ancient Greek texts, what might be her motive? Odysseus upon his return to Ithaka and Oedipus upon his return to Thebes are both "passers" in the sense that they are performing false identities. The difference between them is that Odysseus puts on his disguise knowingly while Oedipus genuinely believes that he is the son of Polybus and must discover that he is actually the son of Laius and Jocasta. This difference between witting and unwitting disguise is precisely what is at issue in the relationship between Brenda and Marion after Mrs. Murray's revelation. Brenda complains to Marion that she feels "a right fool” for being drawn into Marion's lies. ${ }^{119}$ The question in Brenda's mind, then, is whether Marion is a knowing or an unknowing play-white: Is she an Odysseus or an Oedipus? And the moment in her narrative when the double allusion to these figures occurs marks the moment this question would have entered the mind of Brenda the character. Marion would appear as both Odysseus and Oedipus at once, or as a question mark poised between the two, until the matter is cleared up through their discussion the next morning.

The scene that night in Marion's apartment provides another example of an allusion that can come only from the narrating consciousness. On the night of her return from Wuppertal, Marion is beset by a troubling nightmare. Brenda, sleeping on the couch, hears Marion's "eerie cries," climbs into her bed to hold and comfort her, and "like lovers, they wake together." 120 This is a re-enactment of the lines from the Leipoldt poem Brenda had quoted earlier as evidence of Leipoldt's homosexuality. In the second stanza quoted, the poem's speaker says, "Sleep peacefully, curly-headed boy, unconscious of the dreams: soon enough you'll have a nightmare (nagmerrie); who will soothe (sus) you then, little boy?"121

\footnotetext{
${ }^{119}$ Wicomb, Playing in the Light, 102.

${ }^{120}$ Ibid., 99, 100.

${ }^{121}$ I wish to thank my colleague Simon Lewis for providing this translation; there is no published English translation of this poem.
} 
This connection between the scene as narrated and the poem Brenda recited earlier greatly strengthens the argument for a reading of the novel as mostly, if not completely, narrated by Brenda. Although the bed (which had earlier been a sinking ship for Marion) is on one level a sexual metaphor hinting at a possible lesbian attraction between the women, it also functions as an example of narrative "embedding." At the first level of embedding, Brenda is in a subordinate role as an employee and as a guest in Marion's apartment who cannot drive herself home for lack of a car and a driver's license. If both host and guest in this scene are themselves embedded in a narrative authored by Brenda, however, then at this higher level of embedding the power relations are reversed, as Brenda controls both the characters and the way in which their interaction is narrated, including its intertextual connection to Leipoldt's poem. At this level, Brenda becomes the host/driver and we, the readers, are the guests/passengers whose agency consists in how we choose to interpret the scene. If we assume that Brenda is to be understood as both character and narrator, then this scene, like Marion's story of "The Betrayal of Annie Boshoff," appears as a mating of Brenda's experience with her reading.

Brenda's allusion to Eliot's "Prufrock" the next morning is open to a similar double reading. As we have seen, Eliot's poem suits the needs of Brenda the character because of its focus on the anxieties of social belonging and the question of fraudulent self-presentation. But the poem also portrays, via its own intertextuality, the public use by a writer of a story told in private. The lines of Eliot's epigraph are the beginning of Guido's narrative, in which he says that he would not tell his story if he thought that the one listening (Dante) could ever share it in the world of the living. Dante does share it, of course, while narrating his own journey, thus tricking the trickster and exposing him at the same time. Eliot's placing of this epigraph at the start of his poem performs a similar trickery on Prufrock, exposing his petty 
anxieties and grandiose desires to public view. ${ }^{122}$ In Wicomb's novel, Marion attempts to defend herself from the charge of fraud by "telling all" of her life story as she understands it, thus unknowingly providing Brenda the writer with much of the material she would need to write the novel we are reading, and marking the moment at which the novel might have begun to take shape in the mind of Brenda the character. ${ }^{123}$ This moment and its connections to Eliot also prepare us for Marion's later anger at Brenda's fictional use of her family's stories. Thus, when read as coming from within the novel's narrating consciousness, the allusion to Eliot functions as a self-conscious representation of the narrative's "generation," that is, its double origin in, on the one hand, Brenda's hearing of Marion's story and, on the other, Brenda's borrowing of Eliot's intertextual methods for her own purposes. The later references to Marion's readings of Gordimer and Coetzee also suggest that aspects of Marion's "generation" have sprung from Brenda's readings of those texts.

Taken as a group, Brenda's allusions are consistently more learned and more multilayered than those of Helen and Marion. Her citations as a character show a budding writer in process of formation, while her citations as narrator show her mastery over both the actions of her characters and the relation of her text to the literary tradition it will soon join. Viewing them in the context of the other two women, however, raises a further set of questions. To what extent is Brenda as author, knowingly or unknowingly, engaged in her own version of "passing" through her repeated references to white European and South African authors? Has she really taken charge of the intertextual process and turned it to her own ends or is she merely citing famous works to establish her belonging within a privileged literary elite? Wicomb's choice to frame her novel within a secondary frame as Brenda's

\footnotetext{
${ }^{122}$ See Banerjee, “The Dantean Overview,” for a further discussion of Eliot's choice of epigraph. ${ }^{123}$ Wicomb, Playing in the Light, 102.
} 
novel invites but does not settle such questions about Brenda and her motives. Indeed, as a young writer producing a first novel, Brenda might be forgiven for trying a bit too hard to demonstrate her knowledge of "the tradition." As I have described them, however, Brenda's intertextual practices are more than just learned; they are acute and ironic, prompting readers to re-assess the literary tradition and to "destabilize received views" about race, identity, and origins. ${ }^{124}$ In choosing Marion's family as the subject of her fiction, Brenda has written a self-referential, intertextual novel that avoids simple autobiography while still addressing matters of South African political importance.

What, then, of Wicomb herself as author? Is she completely hidden behind the mask of Brenda? We all "know" that she is the ultimate source of all of the novel's strategies, but as soon as we use the words "ultimate source" we realize that this is a concept that the novel has worked hard to destabilize. The novel's sheer range and number of intertextual allusions testify to the fertile and creative process by which texts, like identities, are constructed from multiple elements. Far from trying to conceal its origins, the novel celebrates them, and Wicomb emerges as the expert orchestrator of this process.

\section{Acknowledgment}

I wish to thank Robert Rebein for his valuable advice and mentorship in the preparation of this essay.

\section{References}

Alighieri, Dante. Inferno. Translated by M. Musa. Harmondsworth, England: Penguin Books, 1984.

${ }^{124}$ Wicomb, "Setting," 146. 
Andersen, Hans Christian. The Annotated Hans Christian Andersen. Edited with an introduction and notes by Maria Tatar. Translated by Maria Tatar and Julie K. Allen. New York: W.W. Norton, 2008.

Banerjee, R.D.K. "The Dantean Overview: The Epigraph to 'Prufrock.'" MLN 87, no. 7 (1972): 962-66.

Catenaccio, Claire. "Oedipus Tyrannus: The Riddle of The Feet." The Classical Outlook 89, no. 4 (2012): 102-07.

Daymond, M.J. "'Inventing a New Language for Reconstructing Ourselves': Zoë Wicomb's South African Fiction." Phoenix: Sri Lanka Journal of English in the Commonwealth 8 (2011): 1-12.

---. "Shadow Stories and Shadow Selves: Techniques of Selfhood in Zoë Wicomb's Playing in the Light and the Autobiographical Writing of Agnes Lottering and Rayda Jacobs." Current Writing: Text and Reception in Southern Africa 23, no. 2 (2011): 157-67.

Driver, Dorothy. "The Struggle Over the Sign: Writing and History in Zoë Wicomb's Art." Journal of Southern African Studies 36, no. 3 (2010): 523-42.

Eliot, T. S. “The Love Song of J. Alfred Prufrock.” In Poetry 6, no. 3 (June 1915): 130-135.

Eliot, T.S. "Tradition and the Individual Talent." In The Sacred Wood: Essays On Poetry and Criticism. London: Methuen, 1964.

Erasmus, Zimitri. Coloured by History, Shaped by Place: New Perspectives On Coloured Identites in Cape Town. Cape Town: Kwela Books, 2001.

Gordimer, Nadine. The Conservationist. Harmondsworth: Penguin, 1978.

Herrero, Delores. "Plight versus Right: Trauma and the Process of Recovering and Moving Beyond the Past in Zoë Wicomb's Playing in the Light." In Trauma In Contemporary Literature: Narrative and Representation, eds. Marita Nadal and Mónica Calvo. New York: Routledge, 2014. 
Huddleston, Trevor. Naught for Your Comfort. London: Collins, 1957.

Jacobs, J.U. "Playing in the Dark/Playing in the Light: Coloured Identity in the Novels of Zoë Wicomb." Current Writing: Text and Reception in Southern Africa 20, no. 1 (2008): $1-15$.

McCann, Fiona. "Revisiting the Past: Memory and Identity in Elleke Boehmer's Bloodlines and Zoë Wicomb's David's Story and Playing in the Light." In Trauma, Resistance, Reconstruction in Post-1994 South African Writing, eds. J.K. Singh and R. Chetty. Postcolonial Studies 7. New York: Peter Lang, 2010.

Olaussen, Maria. "Generation and Complicity in Zoë Wicomb's Playing in the Light." In Exit: Endings and New Beginnings in Literature and Life, ed. Stefan Helgesson, Cross/Cultures: Readings in the Post/Colonial Literatures in English. Rodopi, 2011. Robinson, Amy. "It takes one to know one: Passing and communities of common interest." Critical Inquiry 20, no. 4 (1994): 715.

Robolin, Stephane. "Properties of Whiteness: (Post)Apartheid Geographies in Zoë Wicomb's Playing in the Light." Safundi 12, no. 3-4 (2011): 349-71.

Samuelson, Meg. "Oceanic Histories and Protean Poetics: The Surge of the Sea in Zoë Wicomb's Fiction." Journal of Southern African Studies 36, no. 3 (2010): 543-57. Sultan, Stanley. "Tradition and the Individual Talent in 'Prufrock."' Journal of Modern Literature 12, no. 1 (March 1985): 77-90.

Van der Vlies, Andrew. "The Archive, the Spectral, and Narrative Responsibility in Zoë Wicomb's Playing in the Light." Journal of Southern African Studies 36, no. 3 (2010): $583-98$.

Wicomb, Zoë. "Culture beyond Color? A South African Dilemma." Transition 60(1993): 2732. 
---. "Five Afrikaner Texts and the Rehabilitation of Whiteness." Social Identities 4, no. 3 (1998): 363-84.

---. Playing in the Light. New York: New Press, 2006.

---. "Setting, Intertextuality and the Resurrection of the Postcolonial Author." Journal of Postcolonial Writing 41, no. 2 (2005): 144-55.

---. "Shame and Identity: The Case of the Coloured in South Africa." In Writing South Africa: Literature, Apartheid, and Democracy, 1970-1995, eds. Derek Attridge and Rosemary Jolly. Cambridge University Press, 1998.

---. "To Hear the Variety of Discourses." Current Writing: Text and Reception in Southern Africa 2, no. 1 (1990): 35-44.

---. "Tracing the Path from National to Official Culture." In Critical Fictions: The Politics of Imaginative Writing, ed. P. Mariani. Seattle: Bay Press, 1991.

Wicomb, Zoë and Eva Hunter. “Zoë Wicomb Interviewed by Eva Hunter, Cape Town, 5 June 1990." In Between the Lines II: Interviews with Nadine Gordimer, Menan du Plessis, Zoë Wicomb, Lauretta Ngcobo. Grahamstown, SA: National English Literature Museum, 1993, 79-96. 